\title{
Effects of feeding canola meal and sweet lupin (L. luteus, L. angustifolius) in amino acid balanced diets on growth performance and carcass characteristics of growing-finishing pigs
}

\author{
Dora A. Roth-MAIER ${ }^{a *}$, Barbara M. BÖHMER ${ }^{\mathrm{a}}$, Franz X. RotH ${ }^{\mathrm{b}}$ \\ ${ }^{a}$ Division of Animal Nutrition, Technical University Munich, Hochfeldweg 6, \\ 85350 Freising-Weihenstephan, Germany \\ ${ }^{b}$ Division of Animal Nutrition and Production Physiology, Technical University Munich, \\ Hochfeldweg 6, 85350 Freising-Weihenstephan, Germany
}

(Received 23 January 2003; accepted 11 November 2003)

\begin{abstract}
Two trials, each with 48 growing-finishing pigs (30-120 kg), were carried out to evaluate the effect of $25.9 \%$ and $16.2 \%$ of canola meal in the grower and finisher diets, respectively, and the effect of diets containing $20 \%$ sweet lupin (L. luteus or L. angustifolius) with and without enzyme supplementation (Rovabio ${ }^{\mathrm{TM}}$ Excel AP) on growth performance and carcass characteristics. The diets were isoenergetic and considered adequate for protein and amino acids with fixed ratios of limiting amino acids calculated on an apparent ileal digestibility basis. In the canola diets, the glucosinolate content was 2.2 and $1.3 \mathrm{mmol} \cdot \mathrm{kg}^{-1}$ in grower and finisher diets, respectively. The experiment with canola meal showed a significantly better performance in the canola groups than in the control group in the growing period. In the finishing period, the canola groups showed smaller daily gain than the control group. This indicates that the impact of glucosinolates may increase over time and that the content of canola products in the finishing period must be reevaluated in this respect. In the finishing diet, the content should not exceed $0.9 \mathrm{mmol} \cdot \mathrm{kg}^{-1}$ feed. The results of the

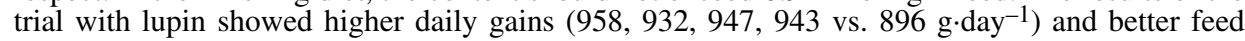
conversion ratio $(2.03,2.06,2.07 \mathrm{vs} .2 .13 \mathrm{~kg}$ feed per kg gain) in the growing period. It is suggested that the inclusion of lupin to replace soybean meal on the ileal digestible amino acid basis is responsible for these positive results. Also, in the finisher period, a significant enzyme effect was observed in feed efficiency in the supplemented groups. The carcass characteristics were not affected by either canola content or lupin variety, or by enzyme supplementation.
\end{abstract}

canola meal / lupin / sweet lupin / growing pig / amino acid balanced diet

Résumé - Effets de rations alimentaires avec farine de colza et lupin doux ( $L$. luteus ou L. angustifolius) dans des régimes équilibrés en acides aminés sur les performances de croissance et les caractéristiques des carcasses de porcs en croissance-finition. Deux essais ont été conduits séparément, chacun sur 48 porcs en croissance-finition (30-120 kg), afin d'évaluer les effets de rations contenant, d'une part, jusqu'à 25,9\% (régimes de croissance) et 16,2\% (régimes de finition) de farine de colza, et d'autre part, $20 \%$ de lupin doux (L. luteus ou L. angustifolius) avec

* Corresponding author: Roth-Maier@wzw.tum.de 
ou sans supplément enzymatique (Rovabio ${ }^{\mathrm{TM}}$ Excel AP) sur les performances de croissance et les caractéristiques des carcasses. Les régimes ont été formulés de façon que les apports énergétiques et protéiques soient adéquates avec des rapports entre acides aminés limitants définis et calculés sur la base de la digestibilité iléale apparente. Dans les régimes avec colza, la teneur en glucosinolate a été, respectivement, jusqu'à 2,2 et $1,3 \mathrm{mmol} \cdot \mathrm{kg}^{-1}$ pour les périodes de croissance et de finition. Dans l'essai avec la farine de colza, les performances des porcs soumis aux régimes avec colza ont été significativement meilleures que celles des porcs du groupe témoin (sans colza) durant la période de croissance. En revanche, pendant la période de finition, les gains de poids quotidiens ont été moindres. Ceci indique que l'impact des glucosinolates peut augmenter dans le temps et que la teneur des résidus de colza dans la période de finition doit être réévaluée en conséquence. Dans le régime de finition, cette teneur ne devrait pas dépasser $0,9 \mathrm{mmol} \cdot \mathrm{kg}^{-1} \mathrm{~d}$ 'aliment. Dans l'essai avec les variétés de lupins doux, les gains de poids quotidiens $(958,932,947,943$ vs. 896 g par jour) ont été supérieurs et l'indice de consommation meilleur (2,03, 2,06, 2,07 vs. 2,13 kg d'aliment par kg de gain) pendant la période de croissance. L'incorporation du lupin en remplacement de la farine de soja sur la base de la digestibilité iléale des acides aminés serait à l'origine de ces résultats positifs. De plus, durant la période de finition, un effet significatif du supplément enzymatique a été observé sur l'indice de consommation. Pour ce qui concerne les caractéristiques des carcasses, elles n'ont été affectées ni par la teneur en colza ni par la variété de lupin ou la supplémentation enzymatique.

farine de colza / lupin / lupin doux / porc en croissance / régime équilibré en acides aminés

\section{INTRODUCTION}

The importance of canola meal and sweet lupin as animal feed is growing with the availability of new varieties with fewer anti-nutritional substances and the need to replace more expensive protein sources. The production of canola oil, and thereby the by-product canola meal [9], is gradually increasing to meet demand. The banning of by-products from terrestrial animals in livestock feed in the European Union has created a need for alternative protein sources [26]. Canola and sweet lupin can help to replace banned protein sources. These seeds may also help to extend the range of available protein feed, especially for organic farms, which need on-farm feed [20]. The nutritional value of both canola and sweet lupin is impaired by anti-nutritional factors such as glucosinolate and alkaloids, and, in particular, the ileal digestibility of non-starch polysaccharides in lupins is low [15]. Apparent ileal digestibility and amino acid content vary widely within genotypes and can affect nutritional value $[6,11]$. Very few data are available on the influence of enzymes in combination with lupin in the diets of pigs, and no data are available on amino acid balanced diets with canola and lupin.
This investigation aims to evaluate whether high contents of canola or lupin with supplementary amino acids were a suitable protein source for growing/finishing pigs. As a follow-up to previous work, it shall be investigated whether the underperformance caused by some lupin varieties could be offset by inclusion of enzymes. These non-starch polysaccharide (NSP) cleaving enzymes are able to hydrolyse pentosanes and glucanes and are therefore liable to increase digestibility and metabolisable energy content. Such increase was clearly shown in previous work [15].

\section{MATERIALS AND METHODS}

In two experiments, each with 48 growing-finishing pigs (German Landrace $\times$ Pietrain, females and castrates), the effects of canola meal and lupin seed meal as protein sources were tested. The pigs were randomly assigned to groups according to litter origin (6 litters), gender (barrows:gilts 1:1), and body weight, and were housed individually in pens in a fully air-conditioned facility at a temperature of $21-22{ }^{\circ} \mathrm{C}$.

The canola meal was a solvent-extracted standard commercial product. Its composition is given in Table I. The glucosinolate 
Table I. Nutrient composition, limiting essential amino acid content, and anti-nutritional factors of canola meal and lupin seeds.

\begin{tabular}{lccc}
\hline & Canola meal & $\begin{array}{c}\text { Lupin } \\
\text { L. angustifolius }\end{array}$ & $\begin{array}{c}\text { Lupin } \\
\text { L. luteus }\end{array}$ \\
\hline Crude protein (\%) & 33.9 & 33.2 & 39.7 \\
Crude fibre (\%) & 15.9 & 14.1 & 12.4 \\
Ether extract (\%) & 3.7 & 7.8 & 7.5 \\
Amino acids (\%) & & & \\
Lysine & 2.07 & 1.70 & 2.10 \\
Methionine & 0.84 & 0.30 & 0.37 \\
Cystine & 0.87 & 0.32 & 0.71 \\
Threonine & 1.47 & 1.09 & 0.30 \\
Tryptophan & 0.49 & 0.30 & \\
Anti-nutritional factors & & & \\
Total glucosinolates (mmol $\cdot \mathrm{kg}^{-1}$ ) \\
of which:
\end{tabular}

${ }^{1}$ Of which: $72.4 \%$ lupanin, $9.7 \%$ 13-hydroxylupanin, $5.1 \%$ isolupanin, $12.8 \%$ angustifolin; ${ }^{2}$ of which: $90 \%$ gramin, $10 \%$ tryptophol.

and vinylthiooxyzolidone (VOT) contents of the canola meal were found to be $8.3 \mathrm{mmol} \cdot \mathrm{kg}^{-1}$ and $604 \mathrm{mg} \cdot \mathrm{kg}^{-1}$, respectively. The analysis was carried out according to methods registered in the Gazette of the EC (1864/90 Nr. L 170/28, 3.7.90).

The lupin seeds were kindly provided by Saatzucht Steinach, 17219 Bocksee, Germany; they were grown in MecklenburgWestern Pomerania, Germany, in 2001. The nutrient content, and the levels of most limiting amino acids, alkaloids, and oligosaccharides are given in Table I. The alkaloids were analysed using high-resolution gas chromatography and GLC-MS measurements (Tei and Wink [34]). The oligosaccharides were extracted according to the method of Quemener [24] and the $\alpha$-galactosides (raffinose, stachyose, verbascose) were analysed by HPLC (Hewlett-Packard 1050) with RI-Detector HP 1047A and HP column (LiChrospor ${ }^{\circledR}$ $100 \mathrm{NH}_{2} 5 \mu \mathrm{m} 250 \times 4 \mathrm{~mm}$ ).

The proximate analysis was carried out according to the official VDLUFA method using the Weender feed analysis system. 
Table II. Composition and nutrient content of the diets with canola meal for growing pigs (\%).

\begin{tabular}{|c|c|c|c|c|}
\hline Ingredients & Group I & Group II & Group III & Group IV \\
\hline Canola meal & 0 & 8.64 & 17.28 & 25.92 \\
\hline Soybean meal & 17.76 & 11.84 & 5.92 & 0 \\
\hline Wheat & 53.58 & 53.54 & 53.52 & 53.50 \\
\hline Barley & 25.00 & 21.43 & 17.87 & 14.30 \\
\hline Vitamin-mineral-premix ${ }^{1}$ & 2.00 & 2.00 & 2.00 & 2.00 \\
\hline Soybean oil & 0.50 & 1.50 & 2.50 & 3.49 \\
\hline $\mathrm{CaCO}_{3}$ & 0.51 & 0.47 & 0.44 & 0.41 \\
\hline $\mathrm{Ca}\left(\mathrm{H}_{2} \mathrm{PO}_{4}\right)_{2 .} \mathrm{H}_{2} \mathrm{O}$ & 0.39 & 0.26 & 0.13 & 0.41 \\
\hline L-Lysine $\mathrm{HCl}$ & 0.21 & 0.26 & 0.29 & 0.32 \\
\hline L-Threonine & 0.03 & 0.04 & 0.04 & 0.04 \\
\hline \multicolumn{5}{|l|}{ Nutrient content (analysed) } \\
\hline Crude protein & 17.5 & 17.5 & 17.5 & 17.5 \\
\hline Ether extract & 2.3 & 3.3 & 4.3 & 5.4 \\
\hline Crude fibre & 3.6 & 4.1 & 4.6 & 5.1 \\
\hline $\mathrm{N}$-free extract & 59.6 & 58.2 & 56.8 & 55.4 \\
\hline Starch & 46.1 & 43.9 & 41.6 & 39.3 \\
\hline Sugars & 3.7 & 3.7 & 3.7 & 3.7 \\
\hline \multicolumn{5}{|c|}{ Apparent digestible amino acids $\left(\mathrm{g} \cdot \mathrm{kg}^{-1}\right)$ : } \\
\hline Lysine & 8.2 & 8.2 & 8.2 & 8.2 \\
\hline Methionine+Cystine & 5.1 & 5.3 & 5.6 & 5.8 \\
\hline Threonine & 5.3 & 5.3 & 5.3 & 5.3 \\
\hline Tryptophan & 1.8 & 1.7 & 1.7 & 1.7 \\
\hline $\mathrm{Ca}\left(\mathrm{g} \cdot \mathrm{kg}^{-1}\right)$, calculated & 8.0 & 8.0 & 8.0 & 8.0 \\
\hline $\mathrm{P}\left(\mathrm{g} \cdot \mathrm{kg}^{-1}\right)$, calculated & 6.6 & 6.0 & 6.1 & 6.2 \\
\hline Energy content $\left(\mathrm{MJ} \mathrm{ME} \cdot \mathrm{kg}^{-1}\right)^{2}$ & 13.1 & 13.1 & 13.1 & 13.1 \\
\hline $\begin{array}{l}\text { Glucosinolate content }\left(\mathrm{mmol} \cdot \mathrm{kg}^{-1}\right. \\
\text { feed), calculated }\end{array}$ & 0 & 0.7 & 1.4 & 2.2 \\
\hline
\end{tabular}

\footnotetext{
${ }^{1}$ Supplement per kg feed: $4.4 \mathrm{~g} \mathrm{Ca}, 1.2 \mathrm{~g} \mathrm{P}, 1 \mathrm{~g} \mathrm{Na}, 0.2 \mathrm{~g} \mathrm{Mg}, 12000$ IE vitamin A, $1200 \mathrm{IE}$ vitamin $\mathrm{D}_{3}$, $7 \mathrm{mg}$ vitamin $\mathrm{K}_{3}, 7 \mathrm{mg}$ vitamin $\mathrm{B}_{1}, 25 \mathrm{mg}$ vitamin $\mathrm{B}_{2}, 15 \mathrm{mg}$ vitamin $\mathrm{B}_{6}, 20 \mu \mathrm{g}$ vitamin $\mathrm{B}_{12}, 30 \mathrm{mg}$ niacin, $60 \mathrm{mg}$ pantothenic acid, $2 \mathrm{mg}$ folic acid, $3000 \mathrm{mg}$ cholin, $1600 \mu \mathrm{g}$ biotin; ${ }^{2}$ calculated according to GfE [12]: $\mathrm{ME}\left(\mathrm{MJ} \cdot \mathrm{kg}^{-1} \mathrm{~T}\right)=0.0210 \mathrm{DXP}+0.0374 \mathrm{DXL}+0.0144 \mathrm{DXF}+0.0171 \mathrm{DXX}-0.0014 \mathrm{SZ}-0.0068(\mathrm{BFS}-100)$.
}

For the trial with canola meal, the pigs were split into 4 experimental groups with 12 animals each (barrows:gilts 1:1). The trial was divided into two phases (growing: 30-60 kg body weight, finishing: 60$117 \mathrm{~kg}$ body weight). For each period, a diet was composed according to the NRC 1998 recommendations [21]. The control group I received a complete feed based on barley and wheat with soybean meal as main protein source, in groups II and III the soybean meal was partially replaced by canola meal and in group IV the soybean meal was completely replaced by canola meal. The composition and nutrient content of the rations are given in Tables II and III. The nutrient content of the feed mixtures used in the respective phases was uniform for all treatment groups at $17.5 / 15.0 \%$ crude protein with $8.2 / 7.2 \mathrm{~g} \cdot \mathrm{kg}^{-1}$ lysine and $13.1 \mathrm{MJ}$ $\mathrm{ME} \cdot \mathrm{kg}^{-1}$ feed. The amino acid contents of the feed mixtures were calculated on an apparent ileal digestibility basis using digestibility coefficients from Degussa 
Table III. Composition and nutrient content of the diet with canola meal for finishing pigs (\%).

\begin{tabular}{|c|c|c|c|c|}
\hline Ingredients & Group I & Group II & Group III & Group IV \\
\hline Canola meal & 0 & 5.40 & 10.80 & 16.18 \\
\hline Soybean meal & 12.06 & 7.90 & 4.01 & 0 \\
\hline Wheat & 50.41 & 50.50 & 50.40 & 50.40 \\
\hline Barley & 34.34 & 32.87 & 30.54 & 28.62 \\
\hline Vitamin-mineral-premix ${ }^{1}$ & 1.35 & 1.35 & 1.35 & 1.35 \\
\hline Soybean oil & 0.50 & 0.98 & 1.72 & 3.34 \\
\hline $\mathrm{CaCO}_{3}$ & 0.58 & 0.32 & 0.56 & 0.54 \\
\hline $\mathrm{Ca}\left(\mathrm{H}_{2} \mathrm{PO}_{4}\right)_{2} \cdot \mathrm{H}_{2} \mathrm{O}$ & 0.29 & 0.19 & 0.09 & 0 \\
\hline $\mathrm{NaCl}$ & 0.12 & 0.13 & 0.13 & 0.14 \\
\hline L-Lysine $\mathrm{HCl}$ & 0.26 & 0.29 & 0.32 & 0.35 \\
\hline L-Threonine & 0.04 & 0.05 & 0.05 & 0.06 \\
\hline \multicolumn{5}{|l|}{ Nutrient content (analysed) } \\
\hline Crude protein & 15.0 & 15.0 & 15.0 & 15.0 \\
\hline Ether extract & 1.7 & 2.3 & 3.2 & 3.8 \\
\hline Crude fibre & 4.5 & 4.9 & 5.3 & 5.7 \\
\hline $\mathrm{N}$-free extract & 61.7 & 60.9 & 59.3 & 58.4 \\
\hline Starch & 48.8 & 47.8 & 46.3 & 45.0 \\
\hline Sugars & 3.2 & 3.2 & 3.2 & 3.2 \\
\hline \multicolumn{5}{|c|}{ Apparent digestible amino acids $\left(\mathrm{g} \cdot \mathrm{kg}^{-1}\right)$ : } \\
\hline Lysine & 7.3 & 7.2 & 7.3 & 7.1 \\
\hline Methionine+Cystine & 4.5 & 4.7 & 4.8 & 5.0 \\
\hline Threonine & 4.7 & 4.7 & 4.7 & 4.5 \\
\hline Tryptophan & 1.5 & 1.5 & 1.4 & 1.4 \\
\hline $\mathrm{Ca}\left(\mathrm{g} \cdot \mathrm{kg}^{-1}\right)$, calculated & 6.6 & 5.6 & 6.6 & 6.6 \\
\hline $\mathrm{P}\left(\mathrm{g} \cdot \mathrm{kg}^{-1}\right)$, calculated & 5.3 & 5.3 & 5.3 & 5.3 \\
\hline Energy content $\left(\mathrm{MJ} \mathrm{ME} \cdot \mathrm{kg}^{-1}\right)^{2}$ & 13.1 & 13.1 & 13.1 & 13.1 \\
\hline $\begin{array}{l}\text { Glucosinolate content } \\
\left(\mathrm{mmol} \cdot \mathrm{kg}^{-1} \text { feed }\right) \text {, calculated }\end{array}$ & 0 & 0.5 & 0.9 & 1.3 \\
\hline
\end{tabular}

\footnotetext{
${ }^{1}$ Supplement per kg feed: $4.4 \mathrm{~g} \mathrm{Ca}, 1.2 \mathrm{~g} \mathrm{P}, 1 \mathrm{~g} \mathrm{Na}, 0.2 \mathrm{~g} \mathrm{Mg}, 12000 \mathrm{IE}$ vitamin A, $1200 \mathrm{IE}$ vitamin $\mathrm{D}_{3}$, $7 \mathrm{mg}$ vitamin $\mathrm{K}_{3}, 7 \mathrm{mg}$ vitamin $\mathrm{B}_{1}, 25 \mathrm{mg}$ vitamin $\mathrm{B}_{2}, 15 \mathrm{mg}$ vitamin $\mathrm{B}_{6}, 20 \mu \mathrm{g}$ vitamin $\mathrm{B}_{12}, 30 \mathrm{mg}$ niacin, $60 \mathrm{mg}$ pantothenic acid, $2 \mathrm{mg}$ folic acid, $3000 \mathrm{mg}$ cholin, $1600 \mu \mathrm{g}$ biotin; ${ }^{2}$ calculated according to GfE [12]: $\mathrm{ME}\left(\mathrm{MJ} \cdot \mathrm{kg}^{-1} \mathrm{~T}\right)=0.0210 \mathrm{DXP}+0.0374 \mathrm{DXL}+0.0144 \mathrm{DXF}+0.0171 \mathrm{DXX}-0.0014 \mathrm{SZ}-0.0068(\mathrm{BFS}-100)$.
}

tables [25]. The following ratio, according to requirement [21], was adopted: lysine/ methionine + cystine/threonine/tryptophan, 1/0.60/0.64/0.19. Amino acid deficiencies were offset, where appropriate, by adding L-lysine-HCl, DL-methionine, L-threonine and L-tryptophan to give all the feed mixtures identical concentrations and ratios of the limiting amino acids.

For the trial with lupin, the 48 pigs were split into 5 experimental groups with 9/
10 animals each. The fattening trial was divided into two phases (growing: 30$60 \mathrm{~kg}$ body weight, finishing: $60-123 \mathrm{~kg}$ body weight). For each period, a diet was composed according to the NRC 1998 recommendations [21]. The control group I received a complete feed based on barley and corn with soybean meal as main protein source, and in the other groups the soybean meal was partially replaced by lupin of the variety Bolivio (Lupinus angustifolius) and 
Table IV. Composition and nutrient content of the diet with lupin (with/without enzymes) for growing pigs (\%).

\begin{tabular}{|c|c|c|c|c|c|}
\hline Ingredients & Group I & Group II & Group III & Group IV & Group V \\
\hline L. angustifolius & - & 20 & 20 & - & - \\
\hline L. luteus & - & - & - & 20 & 20 \\
\hline Rovabio $^{\mathrm{TM}}$ Exel AP-premix & - & - & 0.50 & - & 0.50 \\
\hline Barley & 52.75 & 47.36 & 47.36 & 51.46 & 51.46 \\
\hline Soybean meal & 22.54 & 8.32 & 8.32 & 4.21 & 4.21 \\
\hline Corn & 20.00 & 20.00 & 19.50 & 20.00 & 19.50 \\
\hline Vitamin-mineral-premix ${ }^{1}$ & 2.3 & 2.3 & 2.3 & 2.3 & 2.3 \\
\hline Soybean oil & 1.85 & 1.22 & 1.22 & 1.08 & 1.08 \\
\hline $\mathrm{CaCO}_{3}$ & 0.22 & 0.13 & 0.13 & 0.19 & 0.19 \\
\hline $\mathrm{Ca}\left(\mathrm{H}_{2} \mathrm{PO}_{4}\right)_{2} \mathrm{H}_{2} \mathrm{O}$ & 0.11 & 0.22 & 0.22 & 0.23 & 0.23 \\
\hline L-Lysine $\mathrm{HCl}$ & 0.16 & 0.28 & 0.28 & 0.33 & 0.33 \\
\hline DL-Methionine & 0.02 & 0.89 & 0.09 & 0.08 & 0.08 \\
\hline L-Threonine & 0.02 & 0.07 & 0.07 & 0.08 & 0.08 \\
\hline L-Thryptophan & 0 & 0.02 & 0.02 & 0.03 & 0.03 \\
\hline \multicolumn{6}{|l|}{ Nutrient content (analysed) } \\
\hline Crude protein & 17.6 & 17.6 & 17.6 & 17.6 & 17.6 \\
\hline Ether extract & 3.7 & 3.9 & 3.9 & 3.8 & 3.8 \\
\hline Crude fibre & 4.2 & 5.9 & 5.9 & 5.7 & 5.7 \\
\hline $\mathrm{N}$-free extract & 57.9 & 57.1 & 57.1 & 57.0 & 57.0 \\
\hline Starch & 41.7 & 39.7 & 39.8 & 40.7 & 40.7 \\
\hline Sugars & 3.6 & 3.2 & 3.2 & 2.8 & 2.8 \\
\hline \multicolumn{6}{|c|}{ Apparent digestible amino acids $\left(\mathrm{g} \cdot \mathrm{kg}^{-1}\right)$ : } \\
\hline Lysine & 8.7 & 8.7 & 8.7 & 8.7 & 8.7 \\
\hline Methionine+Cystine & 5.2 & 5.2 & 5.2 & 5.3 & 5.3 \\
\hline Threonine & 5.7 & 5.7 & 5.7 & 5.7 & 5.7 \\
\hline Tryptophan & 1.8 & 1.7 & 1.7 & 1.7 & 1.7 \\
\hline $\mathrm{Ca}\left(\mathrm{g} \cdot \mathrm{kg}^{-1}\right)$, calculated & 7.2 & 7.2 & 7.2 & 7.2 & 7.2 \\
\hline $\mathrm{P}\left(\mathrm{g} \cdot \mathrm{kg}^{-1}\right)$, calculated & 5.6 & 5.6 & 5.6 & 5.6 & 5.6 \\
\hline Energy content $\left(\mathrm{MJ} \mathrm{ME} \cdot \mathrm{kg}^{-1}\right)^{2}$ & 13.1 & 13.1 & 13.1 & 13.1 & 13.1 \\
\hline
\end{tabular}

${ }^{1}$ Supplement per kg feed: $4.4 \mathrm{~g} \mathrm{Ca}, 1.2 \mathrm{~g} \mathrm{P}, 1 \mathrm{~g} \mathrm{Na}, 0.2 \mathrm{~g} \mathrm{Mg}, 12000 \mathrm{IE}$ vitamin A, $1200 \mathrm{IE}$ vitamin $\mathrm{D}_{3}$, $7 \mathrm{mg}$ vitamin $\mathrm{K}_{3}, 7 \mathrm{mg}$ vitamin $\mathrm{B}_{1}, 25 \mathrm{mg}$ vitamin $\mathrm{B}_{2}, 15 \mathrm{mg}$ vitamin $\mathrm{B}_{6}, 20 \mu \mathrm{g}$ vitamin $\mathrm{B}_{12}, 30 \mathrm{mg}$ niacin, $60 \mathrm{mg}$ pantothenic acid, $2 \mathrm{mg}$ folic acid, $3000 \mathrm{mg}$ cholin, $1600 \mu \mathrm{g}$ biotin; ${ }^{2}$ calculated according to GfE [12]: $\mathrm{ME}\left(\mathrm{MJ} \cdot \mathrm{kg}^{-1} \mathrm{~T}\right)=0.0210 \mathrm{DXP}+0.0374 \mathrm{DXL}+0.0144 \mathrm{DXF}+0.0171 \mathrm{DXX}-0.0014 \mathrm{SZ}-0.0068(\mathrm{BFS}-100)$.

the variety Borsaja (Lupinus luteus) with $20 \%$ each. In groups III and V, the diets were supplemented with enzymes (Rovabio $^{\mathrm{TM}}$ Excel AP) at a concentration of $50 \mathrm{mg} \cdot \mathrm{kg}^{-1}$ feed. The enzymes were provided by Aventis Animal Nutrition SA, 42 avenue Aristide-Briand, 92169 Antony, France. Rovabio ${ }^{\mathrm{TM}}$ Excel AP contains endo-1,4- $\beta$-xylanase (Nr. EC 3.2.1.8) and endo-1,3- $\beta$-xylanase (Nr. EC 3.2.1.6). The activity of the supplemented enzymes was analysed by Rhodia, Woodley, UK. The compositions and nutrient contents of the diets are given in Tables IV and V. The nutrient content of the feed mixtures used in the respective phases was uniform for all 
Table V. Composition and nutrient content of the diet with lupin (with/without enzymes) for finishing pigs (\%).

\begin{tabular}{|c|c|c|c|c|c|}
\hline Ingredients & Group I & Group II & Group III & Group IV & Group V \\
\hline L. angustifolius & - & 20 & 20 & - & - \\
\hline L. luteus & - & - & - & 20 & 20 \\
\hline Rovabio $^{\mathrm{TM}}$ Exel AP-premix & - & - & 0.50 & - & 0.50 \\
\hline Barley & 57.99 & 52.58 & 52.58 & 56.61 & 56.61 \\
\hline Corn & 20.00 & 20.00 & 19.50 & 20.00 & 19.50 \\
\hline Soybean meal & 18.15 & 4.05 & 4.05 & 0 & 0 \\
\hline Soybean oil & 1.98 & 1.34 & 1.34 & 1.23 & 1.23 \\
\hline Vitamin-mineral-premix ${ }^{1}$ & 1.26 & 1.28 & 1.28 & 1.28 & 1.28 \\
\hline $\mathrm{CaCO}_{3}$ & 0.56 & 0.46 & 0.45 & 0.52 & 0.52 \\
\hline $\mathrm{Ca}\left(\mathrm{H}_{2} \mathrm{PO}_{4}\right)_{2} \mathrm{H}_{2} \mathrm{O}$ & 0 & 0.11 & 0.11 & 0.12 & 0.12 \\
\hline L-Lysine $\mathrm{HCl}$ & 0.05 & 0.17 & 0.28 & 0.21 & 0.21 \\
\hline DL-Methionine & 0 & 0.01 & 0.01 & 0.004 & 0.004 \\
\hline L-Threonine & 0 & 0.07 & 0.07 & 0.02 & 0.02 \\
\hline L-Thryptophan & 0 & 0.02 & 0.02 & 0.008 & 0.008 \\
\hline \multicolumn{6}{|l|}{ Nutrient content (analysed) } \\
\hline Crude protein & 15.9 & 15.9 & 15.9 & 15.9 & 15.9 \\
\hline Ether extract & 3.7 & 4.2 & 4.2 & 4.1 & 4.1 \\
\hline Crude fibre & 4.4 & 5.6 & 5.6 & 5.1 & 5.1 \\
\hline $\mathrm{N}$-free extract & 59.7 & 59.0 & 59.0 & 59.1 & 59.1 \\
\hline Starch & 43.8 & 41.9 & 41.9 & 42.8 & 42.8 \\
\hline Sugars & 3.3 & 2.9 & 2.9 & 2.5 & 2.5 \\
\hline \multicolumn{6}{|c|}{ Apparent digestible amino acids $\left(\mathrm{g} \cdot \mathrm{kg}^{-1}\right)$ : } \\
\hline Lysine & 6.8 & 6.8 & 6.8 & 6.8 & 6.8 \\
\hline Methionine+Cystine & 4.6 & 4.1 & 4.1 & 4.1 & 4.1 \\
\hline Threonine & 4.9 & 4.5 & 4.5 & 4.5 & 4.5 \\
\hline Tryptophan & 1.6 & 1.3 & 1.3 & 1.3 & 1.3 \\
\hline $\mathrm{Ca}\left(\mathrm{g} \cdot \mathrm{kg}^{-1}\right)$, calculated & 7.2 & 7.2 & 7.2 & 7.2 & 7.2 \\
\hline $\mathrm{P}\left(\mathrm{g} \cdot \mathrm{kg}^{-1}\right)$, calculated & 5.6 & 5.6 & 5.6 & 5.6 & 5.6 \\
\hline Energy content $\left(\mathrm{MJ} \mathrm{ME} \cdot \mathrm{kg}^{-1}\right)^{2}$ & 13.1 & 13.1 & 13.1 & 13.1 & 13.1 \\
\hline
\end{tabular}

${ }^{1}$ Supplement per kg feed: $4.4 \mathrm{~g} \mathrm{Ca}, 1.2 \mathrm{~g} \mathrm{P}, 1 \mathrm{~g} \mathrm{Na}, 0.2 \mathrm{~g} \mathrm{Mg}, 12000 \mathrm{IE}$ vitamin A, $1200 \mathrm{IE}$ vitamin $\mathrm{D}_{3}$, $7 \mathrm{mg}$ vitamin $\mathrm{K}_{3}, 7 \mathrm{mg}$ vitamin $\mathrm{B}_{1}, 25 \mathrm{mg}$ vitamin $\mathrm{B}_{2}, 15 \mathrm{mg}$ vitamin $\mathrm{B}_{6}, 20 \mu \mathrm{g}$ vitamin $\mathrm{B}_{12}, 30 \mathrm{mg}$ niacin, $60 \mathrm{mg}$ pantothenic acid, $2 \mathrm{mg}$ folic acid, $3000 \mathrm{mg}$ cholin, $1600 \mu \mathrm{g}$ biotin; ${ }^{2}$ calculated according to GfE [12]: $\mathrm{ME}\left(\mathrm{MJ} \cdot \mathrm{kg}^{-1} \mathrm{~T}\right)=0.0210 \mathrm{DXP}+0.0374 \mathrm{DXL}+0.0144 \mathrm{DXF}+0.0171 \mathrm{DXX}-0.0014 \mathrm{SZ}-0.0068$ (BFS-100).

treatment groups at $17.6 / 15.9 \%$ crude protein with $8.7 / 6.8 \mathrm{~g} \cdot \mathrm{kg}^{-1}$ lysine and $13.1 \mathrm{MJ}$ $\mathrm{ME} \cdot \mathrm{kg}^{-1}$ feed. The ratio and supplementation of the essential amino acids was as described in the canola experiment.

In both experiments, feed and water were offered ad libitum. Growth performance (daily weight gain, feed intake, feed conversion efficiency) and various carcass characteristics (carcass yield, ham, fat area above eye muscle, area of eye muscle, fat/ lean ratio, lean meat, classification, meat lightness) were recorded. The mathematical and statistical evaluation of the data was performed by one-way analysis of variance, and if the model was significant $(P<0.05)$, 
Table VI. Effect of replacing soybean meal by canola meal on the performance of grower/finisher pigs.

\begin{tabular}{|c|c|c|c|c|c|c|}
\hline $\begin{array}{l}\text { Proportion of canola meal in the } \\
\text { diets }(\%)^{1}\end{array}$ & $\begin{array}{l}\text { Group I } \\
0 / 0\end{array}$ & $\begin{array}{l}\text { Group II } \\
8.6 / 5.4\end{array}$ & $\begin{array}{c}\text { Group III } \\
17.3 / 10.8\end{array}$ & $\begin{array}{l}\text { Group IV } \\
25.9 / 16.2\end{array}$ & RSD & Significance \\
\hline Weight at beginning of period I ( $\mathrm{kg})$ & 32.7 & 33.0 & 32.8 & 32.7 & & \\
\hline Weight at end of period II $(\mathrm{kg})$ & 117.8 & 117.2 & 117.8 & 116.9 & 2.6 & NS \\
\hline \multicolumn{7}{|l|}{ I. Growing (30-60 kg body weight) } \\
\hline Daily weight gain $\left(\mathrm{g} \cdot \mathrm{day}^{-1}\right)$ & $775^{\mathrm{b}}$ & $806^{\mathrm{ab}}$ & $829^{a}$ & $788^{b}$ & 37 & $* *$ \\
\hline Feed intake $\left(\mathrm{kg} \cdot \mathrm{day}^{-1}\right)$ & 1.72 & 1.75 & 1.74 & 1.72 & 0.02 & NS \\
\hline Feed efficiency ( $\mathrm{kg}$ feed per $\mathrm{kg}$ gain) & $2.23^{\mathrm{a}}$ & $2.17^{\mathrm{ab}}$ & $2.11^{\mathrm{b}}$ & $2.19^{\mathrm{ab}}$ & 0.08 & $*$ \\
\hline Weight at end of period $\mathrm{I}(\mathrm{kg})$ & $59.9^{\mathrm{b}}$ & $61.3^{\mathrm{a}}$ & $61.6^{\mathrm{a}}$ & $60.4^{\mathrm{ab}}$ & 1.3 & $* *$ \\
\hline \multicolumn{7}{|l|}{ II. Finishing (60-117 kg body weight) } \\
\hline Daily weight gain $\left(\mathrm{g} \cdot \mathrm{day}^{-1}\right)$ & $937^{\mathrm{a}}$ & $913^{\mathrm{ab}}$ & $894^{\mathrm{ab}}$ & $858^{\mathrm{b}}$ & 65 & $*$ \\
\hline Feed intake $\left(\mathrm{kg} \cdot \mathrm{day}^{-1}\right)$ & 2.56 & 2.52 & 2.53 & 2.48 & 0.1 & NS \\
\hline Feed efficiency ( $\mathrm{kg}$ feed per kg gain) & 2.74 & 2.77 & 2.84 & 2.91 & 0.19 & NS \\
\hline \multicolumn{7}{|l|}{ Fattening period $I+I I$} \\
\hline Daily weight gain $\left(g \cdot\right.$ day $\left.^{-1}\right)$ & 879 & 873 & 871 & 834 & 47 & NS \\
\hline Feed intake $\left(\mathrm{kg} \cdot\right.$ day $\left.^{-1}\right)$ & 2.26 & 2.24 & 2.25 & 2.22 & 0.07 & NS \\
\hline Feed efficiency ( $\mathrm{kg}$ feed per kg gain) & 2.57 & 2.57 & 2.59 & 2.67 & 0.15 & NS \\
\hline Duration of period I + II (days) & 97.3 & 96.7 & 97.9 & 101.1 & 4.9 & NS \\
\hline
\end{tabular}

${ }^{1}$ Grower/finisher diet; RSD: residual standard deviation; ${ }^{\text {a, b}: ~ w i t h i n ~ a ~ r o w, ~ m e a n s ~ w i t h ~ d i f f e r e n t ~ s u p e r s c r i p t s ~}$ differ significantly $(n=12)$; NS: $P>0.05, *: P<0.05, * *: P<0.01$.

then the group means were examined for statistically significant differences using the Student-Newman-Keuls test. In addition, the effects of lupin variety and enzyme supplementation were examined by 2 -factorial analysis of variance. The effect of the canola content was tested on linear or quadratic effects of the inclusion level. In the tables, arithmetic means of the individual values are presented.

\section{RESULTS}

The performance of the pigs (daily weight gain, daily feed intake, feed conversion efficiency) in the trial with canola meal is given in Table VI. The final weight was determined at $117 \mathrm{~kg}$. In the growing phase, the daily weight gain between the treatments was significantly different $(P<$ 0.01). Group III showed the highest gain and there was no difference between group I (soybean meal) and group IV (canola meal). The feed intake was not affected by the proportion of canola meal in the diets. The feed conversion efficiency showed significant differences $(P<0.05)$ for the amount of feed required per $\mathrm{kg}$ gain and had a significant quadratic effect $(P<$ 0.008 ). The best efficiency was reached in group III, while group I attained the highest level (2.11 vs. $2.23 \mathrm{~kg} \cdot \mathrm{kg}^{-1}$ gain). This resulted in significant differences $(P<$ $0.01)$ in the body weight of the groups at the end of period I (35 days).

In the finishing phase, the only significant difference occurred in the daily weight gain $(P<0.05)$ with a significant linear effect $(P<0.009)$. The highest daily weight gain was recorded in the control group I, the lowest in group IV (937 vs. $858 \mathrm{~g} \cdot \mathrm{day}^{-1}$ ). Feed intake and feed conversion efficiency of the groups showed no significant differences. Regarding the whole fattening 
Table VII. Effect of replacing soybean meal by canola meal on slaughter data of finisher pigs.

\begin{tabular}{|c|c|c|c|c|c|c|}
\hline $\begin{array}{l}\text { Canola meal }(\%) \text { in the } \\
\text { diets } 1\end{array}$ & $\begin{array}{c}\text { Group I } \\
0 / 0\end{array}$ & $\begin{array}{l}\text { Group II } \\
8.6 / 5.4\end{array}$ & $\begin{array}{c}\text { Group III } \\
17.3 / 10.8\end{array}$ & $\begin{array}{c}\text { Group V } \\
25.9 / 16.2\end{array}$ & RSD & Significance \\
\hline Slaughter weight (kg) & 117.8 & 117.2 & 117.8 & 116.9 & 2.7 & NS \\
\hline Carcass yield (\%) & 79.4 & 79.1 & 79.1 & 79.2 & 1.1 & NS \\
\hline $\operatorname{Ham}(\%)$ & 33.5 & 33.5 & 33.3 & 33.5 & 0.9 & NS \\
\hline $\begin{array}{l}\text { Fat area above eye muscle } \\
(\mathrm{mm})\end{array}$ & 17.7 & 20.1 & 21.2 & 19.7 & 3.2 & NS \\
\hline Area of eye muscle (mm) & 57.1 & 58.1 & 57.1 & 55.4 & 3.7 & NS \\
\hline Fat:lean & 0.31 & 0.35 & 0.38 & 0.36 & 0.07 & NS \\
\hline Lean meat $(\%)$ & 58.4 & 57.7 & 57.3 & 56.4 & 2.3 & NS \\
\hline Classification $^{2}$ & 1.8 & 2.0 & 1.9 & 2.0 & 0.6 & NS \\
\hline Meat colour $(\text { Goefo })^{3}$ & 67.0 & 67.7 & 67.4 & 67.7 & 7.8 & NS \\
\hline Thyroid gland (g) & 10.3 & 8.6 & 13.1 & 10.0 & - & - \\
\hline $\begin{array}{l}\text { Thyroid gland }\left(\mathrm{g} \cdot \mathrm{kg}^{-1} \text { body }\right. \\
\text { weight) }\end{array}$ & 0.09 & 0.07 & 0.11 & 0.09 & - & - \\
\hline
\end{tabular}

${ }^{1}$ Grower/finisher diet; ${ }^{2}$ according to quality class: $\mathrm{EE}=1, \mathrm{E}=2, \mathrm{U}=3, \mathrm{R}=4 ;{ }^{3}$ lightness, given as reflection capacity measured with (Goettinger) photometer; RSD: residual standard deviation; NS: $P>0.05$, *: $P<0.05$, **: $P<0.01, n=12$.

period (I+II), no significant differences were observed for the recorded parameters.

The slaughter data for the fattening trial with canola meal are given in Table VII. No significant differences were found for carcass yield, proportion of ham, fat layer, area of eye muscle, fat:lean, and lean meat. Neither the classification of the meat nor the meat lightness (Goefo colour points) was affected by the diets. The weight of the thyroid gland was highly variable, with no direct reference to the proportion of canola meal in the diets, and was probably influenced by the exactness of slicing. No sexrelated effect was observed except that females had less fat and more lean meat $(P<0.05)$.

The performance of the pigs in the trial with lupin is given in Table VIII. The final weight of all groups and the duration of the fattening period were similar. In the growing phase, all parameters showed significant differences between the experimental groups with the lowest level for every parameter in the lupin-free control group I $(P<0.05)$. The enzyme-supplemented groups generally showed similar values compared with the enzyme-free lupin groups. Daily weight gain was best in group II (958 g.day ${ }^{-1}$ ) and lowest in the control group I (896 g.day $\left.{ }^{-1}\right)$. The feed intake was not affected by the diets. The amount of feed required per $\mathrm{kg}$ gain was lower with all the lupin-supplemented diets compared with the lupin-free group, with differences of up to $100 \mathrm{~g}$ feed per $\mathrm{kg}$ gain. Thus the body weight at the end of the period I was lowest in the control group I $(68.5 \mathrm{~kg})$. For the whole fattening period, significant differences $(P<0.01)$ were found only for the parameter feed intake, where group III showed the highest intake with $2.44 \mathrm{~kg} \cdot \mathrm{day}^{-1}$ and group I had only $2.40 \mathrm{~kg} \cdot \mathrm{day}^{-1}$. The enzyme-supplemented groups had a significant lower feed intake than the enzyme-free groups. No significant differences were found for the main effects of lupin variety and enzyme supplementation on growth performance or slaughter characteristics except for one significance for feed efficiency in the finishing period (Tab. IX). Enzyme supplemented groups had better values for feed efficiency ( 2.83 vs. $2.91 \mathrm{~kg}$ feed per $\mathrm{kg}$ gain). 
Table VIII. Effect of replacement of soybean meal by lupin with or without enzymes on performance of grower/finisher pigs.

\begin{tabular}{|c|c|c|c|c|c|c|c|}
\hline $\begin{array}{l}\text { Lupin variety } \\
\text { Proportion of lupin seed }(\%) \\
\text { Enzyme }\end{array}$ & Group I & $\begin{array}{c}\text { Group II } \\
\text { L. ang. } \\
20 \\
-\end{array}$ & $\begin{array}{c}\text { Group III } \\
\text { L. ang. } \\
20 \\
+\end{array}$ & $\begin{array}{c}\text { Group IV } \\
\text { L. luteus } \\
20 \\
-\end{array}$ & $\begin{array}{c}\text { Group V } \\
\text { L. luteus } \\
20 \\
+\end{array}$ & RSD & Significance \\
\hline $\begin{array}{l}\text { Weight at begin of period I } \\
(\mathrm{kg})\end{array}$ & 37.1 & 37.4 & 37.3 & 38.5 & 38.0 & & \\
\hline $\begin{array}{l}\text { Weight at end of period II } \\
(\mathrm{kg})\end{array}$ & 122.2 & 123.0 & 122.6 & 122.1 & 123.2 & 2.6 & NS \\
\hline \multicolumn{8}{|c|}{ I. Growing (30-60 kg body weight) } \\
\hline Daily weight gain $\left(\mathrm{g} \cdot \mathrm{day}^{-1}\right)$ & $896^{\mathrm{b}}$ & $958^{\mathrm{a}}$ & $932^{\mathrm{a}}$ & $947^{\mathrm{a}}$ & $943^{\mathrm{a}}$ & 37 & $*$ \\
\hline Feed intake $\left(\mathrm{kg} \cdot \mathrm{day}^{-1}\right)$ & 1.91 & 1.94 & 1.92 & 1.96 & 1.95 & 0.02 & NS \\
\hline $\begin{array}{l}\text { Feed efficiency ( } \mathrm{kg} \text { feed per } \\
\text { kg gain) }\end{array}$ & $2.13^{\mathrm{a}}$ & $2.03^{\mathrm{b}}$ & $2.06^{\mathrm{ab}}$ & $2.07^{\mathrm{ab}}$ & $2.07^{\mathrm{ab}}$ & 0.08 & * \\
\hline Weight at end of period I $(\mathrm{kg})$ & $68.5^{\mathrm{c}}$ & $70.9^{\mathrm{ab}}$ & $69.9^{\mathrm{b}}$ & $71.6^{\mathrm{a}}$ & $71.0^{\mathrm{ab}}$ & 1.3 & $*$ \\
\hline \multicolumn{8}{|c|}{ II. Finishing (60-123 kg body weight) } \\
\hline Daily weight gain $\left(\mathrm{g} \cdot \mathrm{day}^{-1}\right)$ & 966 & 949 & 972 & 939 & 963 & 44 & NS \\
\hline Feed intake $\left(\mathrm{kg} \cdot \mathrm{day}^{-1}\right)$ & $2.72^{\mathrm{b}}$ & $2.74^{\mathrm{a}}$ & $2.73^{\mathrm{ab}}$ & $2.75^{\mathrm{a}}$ & $2.74^{\mathrm{ab}}$ & 0.01 & $*$ \\
\hline $\begin{array}{l}\text { Feed efficiency ( } \mathrm{kg} \text { feed per } \\
\text { kg gain) }\end{array}$ & 2.82 & 2.89 & 2.81 & 2.93 & 2.84 & 0.13 & NS \\
\hline \multicolumn{8}{|l|}{ Fattening period I + II } \\
\hline Daily weight gain $\left(\mathrm{g} \cdot \mathrm{day}^{-1}\right)$ & 939 & 953 & 957 & 940 & 956 & 35 & NS \\
\hline Feed intake $\left(\mathrm{kg} \cdot \mathrm{day}^{-1}\right)$ & $2.40^{\mathrm{c}}$ & $2.43^{\mathrm{ab}}$ & $2.41^{b c}$ & $2.44^{\mathrm{a}}$ & $2.42^{\mathrm{ab}}$ & 0.02 & $*$ \\
\hline $\begin{array}{l}\text { Feed efficiency ( } \mathrm{kg} \text { feed per } \\
\mathrm{kg} \text { gain) }\end{array}$ & 2.57 & 2.55 & 2.52 & 2.60 & 2.54 & 0.10 & NS \\
\hline Days & 90.7 & 90.0 & 89.3 & 89.1 & 89.2 & 3.5 & NS \\
\hline
\end{tabular}

L. ang.: L. angustifolius; RSD: residual standard deviation; $;$, b, $\mathrm{c}$ : within a row, means with different superscripts differ significantly; NS: $P>0.05, *: P<0.05, * *: P<0.01$, Group I, III, V: $n=10$, Group II, IV: $n=9$.

The slaughter data for the trial with lupin seed meal are listed in Table X. There was no adverse effect of the variety or inclusion level of lupins in the diets. The carcass yield was very uniform. For the area of eye muscle, only group II showed a lower level of $6 \%$ compared with the control group I, while the other groups were similar. The data for the percentage of lean meat were almost uniform. The classification level was similar for all the groups. No significant differences were observed for the evaluation of the main effects of lupin variety and enzyme supplementation on carcass characteristics. No sex-related effect was observed except that females had less fat and more lean meat $(P<0.05)$.

\section{DISCUSSION}

In the trial with canola meal, the inclusion levels of the experimental diets ranged from $8.6 / 5.4$ to $25.9 / 16.2 \%$ for the grower/ finisher diet, respectively, with $8.3 \mathrm{mmol}$ glucosinolates per kg canola meal. Therefore, the calculated level of glucosinolates in the diets of the experimental groups was 2.2/1.3 mmol $\cdot \mathrm{kg}^{-1}$ feed in the grower/finisher diets. In other reports, the levels of rape by-products amounted to $15 \%$ with glucosinolates at $4.3 \mathrm{mmol} \cdot \mathrm{kg}^{-1}$ feed [4, $22,32]$. In this study, the inclusion level is higher, however, with lower levels of glucosinolates in the composed feed. 
Table IX. Main effects of lupin variety and enzyme supplementation on performance of grower/ finisher pigs.

\begin{tabular}{|c|c|c|c|c|c|c|c|}
\hline Parameter & \multicolumn{2}{|c|}{$\begin{array}{l}\text { Lupin effect } \\
\text { L. ang. L. luteus }\end{array}$} & Significance $^{1}$ & \multicolumn{2}{|c|}{$\begin{array}{c}\text { Enzyme effect } \\
\text { no enzymes with enzymes }\end{array}$} & Significance & $\mathrm{RSD}$ \\
\hline Weight at end of period II $(\mathrm{kg})$ & ) 122.8 & 122.7 & NS & 122.8 & 122.6 & NS & 2.57 \\
\hline \multicolumn{8}{|c|}{ I. Growing (30-60 kg body weight) } \\
\hline Daily weight gain $\left(\mathrm{g} \cdot\right.$ day $\left.^{-1}\right)$ & 945 & 944 & NS & 953 & 937 & NS & 38 \\
\hline Feed intake $\left(\mathrm{kg} \cdot \mathrm{day}^{-1}\right)$ & 1.96 & 1.93 & NS & 1.96 & 1.93 & NS & 0.02 \\
\hline $\begin{array}{l}\text { Feed efficiency ( } \mathrm{kg} \text { feed per } \\
\mathrm{kg} \text { gain) }\end{array}$ & 2.08 & 2.05 & NS & 2.05 & 2.07 & NS & 0.07 \\
\hline Weight at end of period $\mathrm{I}(\mathrm{kg})$ & 71.3 & 70.4 & NS & 71.2 & 70.4 & NS & 1.3 \\
\hline \multicolumn{8}{|c|}{ II. Finishing (60-123 kg body weight) } \\
\hline Daily weight gain $\left(\mathrm{g} \cdot \mathrm{day}^{-1}\right)$ & 961 & 950 & NS & 968 & 943 & NS & 41 \\
\hline Feed intake $\left(\mathrm{kg} \cdot \mathrm{day}^{-1}\right)$ & 2.74 & 2.73 & NS & 2.74 & 2.73 & NS & 0.02 \\
\hline $\begin{array}{l}\text { Feed efficiency (kg feed per } \\
\text { kg gain) }\end{array}$ & 2.89 & 2.85 & NS & 2.91 & 2.83 & $*$ & 0.12 \\
\hline \multicolumn{8}{|l|}{ Fattening period $I+I I$} \\
\hline Daily weight gain $\left(\mathrm{g} \cdot \mathrm{day}^{-1}\right)$ & 955 & 949 & NS & 957 & 947 & NS & 34 \\
\hline Feed intake $\left(\mathrm{kg} \cdot \mathrm{day}^{-1}\right)$ & 2.43 & 2.42 & NS & 2.43 & 2.42 & NS & 0.02 \\
\hline $\begin{array}{l}\text { Feed efficiency (kg feed } \\
\text { per kg gain) }\end{array}$ & 2.57 & 2.54 & NS & 2.57 & 2.53 & NS & 0.09 \\
\hline Days & 89.6 & 89.2 & NS & 89.6 & 89.3 & NS & 3.1 \\
\hline
\end{tabular}

L. ang.: L. angustifolius; NS: $P>0.05, *: P<0.05$; RSD: residual standard deviation.

Table X. Effect of replacement of soybean meal by lupin with or without enzyme supplementation on slaughter data of finisher pigs.

\begin{tabular}{|c|c|c|c|c|c|c|c|}
\hline Lupin variety & Group I & $\begin{array}{l}\text { Group II } \\
\text { L. ang. }\end{array}$ & $\begin{array}{l}\text { Group III } \\
\text { L. ang. }\end{array}$ & $\begin{array}{l}\text { Group IV } \\
\text { L. luteus }\end{array}$ & $\begin{array}{l}\text { Group } \mathrm{V} \\
\text { L. luteus }\end{array}$ & RSD & Significance \\
\hline $\begin{array}{l}\text { Proportion of lupin seed in } \\
\text { the diets }(\%)\end{array}$ & 0 & 20 & 20 & 20 & 20 & & \\
\hline Enzyme & - & - & + & - & + & & \\
\hline Slaughter weight (kg) & 122.2 & 123.0 & 122.6 & 122.1 & 123.2 & 2.6 & NS \\
\hline Carcass yield (\%) & 78.9 & 77.7 & 78.4 & 78.2 & 78.5 & 1.3 & NS \\
\hline Fat (mm) & 16.4 & 15.3 & 15.4 & 15.5 & 16.5 & 1.4 & NS \\
\hline Area of eye muscle $\left(\mathrm{mm}^{2}\right)$ & 63.2 & 59.3 & 63.4 & 61.7 & 62.4 & 7.0 & NS \\
\hline Lean meat $(\%)$ & 56.6 & 56.8 & 57.6 & 57.2 & 56.7 & 1.9 & NS \\
\hline Classification $^{1}$ & 2.1 & 2.3 & 2.0 & 2.0 & 2.1 & 0.5 & NS \\
\hline
\end{tabular}

L. ang.: L. angustifolius; RSD: residual standard deviation; NS: $P>0.05, *: P<0.05, * *: P<0.01$, group I, III, V: $n=10$, group II, IV: $n=9 ;{ }^{1}$ according to quality class: $\mathrm{EE}=1, \mathrm{E}=2, \mathrm{U}=3, \mathrm{R}=4$.

No impact on growth performance was observed in the experiment (period I+II). Inclusion of canola meal improved growth in the grower period and only the highest inclusion level of canola meal reduced growth in the finisher period. Slaughter data were not affected by the level of canola in the diets. These findings conflict with those 
of other studies. Wetscherek [35, 36] reported a downturn of $41 \mathrm{~g}$ in feed intake, a decrease of $10 \%$ in feed conversion efficiency, and higher carcass fat content with $15 \%$ canola meal in the diet. With $13.2 \%$ canola meal, he found a decrease of $8 \%$ in daily gain and $6 \%$ in feed conversion efficiency with no impact on carcass, meat, or fat quality. Reduced growth rate and feed conversion efficiency, together with decreased daily gains and prolonged fattening period with increasing proportion of canola meal are the most frequently recorded results $[8,16,22]$.

The decreasing effect of inclusion of canola on growth performance appeared in the finishing period with a significant reduction in daily weight gain. This is in agreement with other reports $[1,14,30]$.

The glucosinolate content of rapeseed ranges widely depending on variety and origin. Unfortunately, only few data on detrimental levels of glucosinolate content (absolute) in the rations are available. Most of the reported results are on the basis of percentage of rapeseed in the diet and are not linked to glucosinolate content. The given recommendations range from 1.2/ $1.4 \mathrm{mmol} \cdot \mathrm{kg}^{-1}$ feed to $3-4 \mathrm{mmol} \cdot \mathrm{kg}^{-1}$ feed, or in terms of the content in the seed, from $5 \mathrm{mmol} \cdot \mathrm{kg}^{-1}$ seed up to $10 \mathrm{mmol} \cdot \mathrm{kg}^{-1}$ seed and up to $20 \mathrm{mmol} \cdot \mathrm{kg}^{-1}$ rape product [16, $30,35]$. The most universal recommendation limits the glucosinolate content in feed to $2.5 \mathrm{mmol} \cdot \mathrm{kg}^{-1}$ feed, including all metabolites $[31,36]$. Based on the significant performance parameter and the glucosinolate content in the experimental groups in this study, it is demonstrated that grower pigs tolerate at least $2.2 \mathrm{mmol}$ glucosinolates $\cdot \mathrm{kg}^{-1}$ feed, whereas finishing pigs are much more sensitive to the glucosinolate content and tolerate only up to $0.9 \mathrm{mmol} \cdot \mathrm{kg}^{-1}$ feed.

The trial with lupin had inclusion levels of $20 \%$ L. angustifolius or L. luteus with or without enzyme supplementation, respectively. The alkaloid content of the lupins was 0.05 and $0.23 \%$, respectively. The alkaloid level for L. luteus was high com- pared with other trials [29]. The analysed amino acid content (lysine, methionine, cystine, threonine, tryptophan) in L. angustifolius was lower than in L. luteus. In this study, no detrimental effect of lupin inclusion on growth performance or slaughter characteristics was found. Lupin variety or enzyme supplementation had no effect on growth or slaughter parameters except for the improved feed efficiency in the finishing period achieved by enzyme supplementation. This conflicts with previous reports. Especially with high levels of lupin (>20\%) in the rations, there are adverse effects (e.g. reduction of daily gain and feed intake) [2, $5,10]$. The detrimental influence of varieties on performance has been shown in experiments with $L$. angustifolius, $L$. luteus, and $L$. albus [5, 17, 23]. The inclusion of L. albus in diets is detrimental probably because of the accumulation of the trace element manganese, which is partially blamed for poor feed intake [27]. King [17] found depressed growth rate and feed conversion efficiency with levels of 20 and $30 \%$ L. albus. Roth-Maier and Paulicks [29], in a previous experiment with $20 \%$ L. angustifolius and L.luteus, found a slight impact on feed conversion efficiency and carcass classification and with $20 \%$ L. angustifolius a reduction of 5\% in daily weight gain. Bellof et al. [4] reported significantly impaired slaughter characteristics with $12 / 18 \%$ lupin in the diets $(0.11 \%$ alkaloids in the lupins).

According to Kluge et al. [18], the different proportions of anti-nutritional factors such as alkaloids and oligosaccharides in the different varieties are a conclusive explanation for these interactions. Some authors have conducted other investigations to improve the nutritional value of lupin, such as dehulling or autoclaving before feeding $[3,10]$.

Another consideration is the addition of single amino acids. As reported by Cheeke et al. [7] and Godfrey [13], alkaloids can have some impact on the metabolism of amino acids, and additionally, there is a 
reduction in feed intake, which can reach the point of total refusal of feed. Kracht et al. [19] showed an increase in feed conversion efficiency in diets with levels of 10-31\% lupin (L. albus) with additional supplementation of lysine, while addition of lysine or methionine had no effect according to Taverner [33].

No results are available on the supplementation of lupin diets with amino acids on the basis of ileal digestibility. The present results demonstrate that the addition of limiting amino acids according to requirements on an ileal digestibility basis may help to amend the effects of lupin in grower/finisher pigs regardless of the levels of alkaloids or other anti-nutritional factors. For the composition of lupin diets, therefore, ileal digestibility of amino acids of lupin should be taken into consideration as it differs, especially for methionine, from the ileal digestibility of the amino acids from soybean meal.

Very few data are available concerning lupin diets and the effect of enzymes on lupin diets for pigs. In a previous study with piglets [28], no effect of enzyme supplementation (200 mg Roxazyme $\mathrm{G}$ per $\mathrm{kg}$ feed) to diets with $15 \%$ L. albus and $30 \%$ L. luteus was found. In the present study, a significant improvement of feed efficiency in the finishing period was observed. These results could probably be improved with another enzyme mixture or dosage.

From the results of this experiment, it is finally concluded that $20 \%$ lupin, even with a high alkaloid content, has no detrimental impact on growth or slaughter performance; presumably the diet is amino acid balanced on an apparent ileal digestible basis. In addition, supplementation with enzymes can be beneficial for feed conversion efficiency.

\section{ACKNOWLEDGEMENTS}

We are grateful to Dr. T. Eckardt, Saatzucht Steinach, Bocksee, Germany for the gift of lupin seeds. We thank Prof. Dr. K. Eder and Dr. H. Kluge, Institut für Ernaehrungswissenschaften, Martin-Luther-Universitaet Halle-Wittemberg,
Germany, for the analysis of oligosaccharides in the lupin seeds, and Dr. M. Wink, Institut für Pharmazeutische Biologie der Ruprecht-KarlsUniversitaet Heidelberg, Germany, for the analysis of alkaloids in the lupin seeds. This work was supported by the Bayerische Arbeitsgemeinschaft Tierernährung e.V. (BAT) FreisingWeihenstephan.

\section{REFERENCES}

[1] Bell J.M., Anderson D.M., Shires A., Evaluation of candle rapeseed meal as a protein supplement for swine, Can. J. Anim. Sci. 61 (1981) 453-461.

[2] Barnett C.W., Batterham E.S., Lupinus angustifolius $\mathrm{cv}$. Unicrop as a protein- and energy-source for weaner pigs, Anim. Feed Sci. Technol. 6 (1981) 27-34.

[3] Batterham E.S., Andersen L.M., Lowe R.F., Darnell R.E., Nutritional value of lupin (Lupinus albus)-seed meal for growing pigs: availability of lysine, effect of autoclaving and net energy content, Brit. J. Nutr. 56 (1986) 645659.

[4] Bellof G., Sieghart S., Sweet lupins and rapeseed cake: Protein alternatives in pig fattening? DGS-Magazin 2 (1996) 45-49.

[5] Bugnacka D., Falkowski J., The effect of dietary levels of yellow lupin seeds (Lupinus luteus L.) on feed preferences and growth performance of young pigs, J. Anim. Feed Sci. 10 (2001) 133-142.

[6] Campos-Andrada M.P., Santana F.M.C., Felgueiras I., Mimoso M.J., Empis J.M.A., Nutritional valule of Lupinus angustifolius and $L$. cosentinii accessions with diverse genetic origin, in: Proceedings of the 9th International Lupin Conference, Klink/Müritz, Germany, 1999, pp. 414-418.

[7] Cheeke P.R., Kelly J.D., Metabolism, toxicity and nutritional implications of quinolizidine (lupin) alkaloids, in: Huisman J., Ban der Poel T.F.B., Liener I.E. (Eds.), Recent advances of research in antinutritional factors in legume seeds, Proc. First Int. Workshop on "Antinutritional Factors (ANF) in Legume Seeds", November 23-25, 1988, Wageningen, The Netherlands, Pudoc Wageningen, 1989.

[8] Corino C., Baldi A., Contempo V., Influence of low-glucosinolate rapeseed meal on performance and thyroid hormone status of heavy pigs, Anim. Feed Sci. Technol. 35 (1991) 321-331.

[9] FEDIOL-Statistic: Oil world, http://www. fediol.be.

[10] Fernandez J.A., Batterham E.S., The nutritive value of lupin-seed and dehulled lupin-seed meals as protein sources for growing pigs as 
evaluated by different techniques, Anim. Feed Sci. Technol. 53 (1995) 279-296.

[11] Gdala J., Smulikowska S., Udunczyk Z., Pastuszewska B., Nutrients and antinutrients in three lupin species grown in Poland, in: Proceedings of the 9th International Lupin Conference, Klink/Müritz, Germany, 1999, pp. 425-431.

[12] GfE (Gesellschaft für Ernährungsphysiologie). Energie- und Nährstoffbedarf landwirtschaftlicher Nutztiere; Nr. 4 Schweine, DLGVerlag, Frankfurt/Main, 1987.

[13] Godfrey N.W., Mercy A.R., Emms Y., Payne H.G., Tolerance of growing pigs to lupin alkaloids, Aust. J. Exp. Agric. 25 (1985) 791-795.

[14] Henkel M., Mosenthin R., Rapssaat und Rapsprodukte in der Tierernährung, Übers. Tierern. 17 (1989) 139-190.

[15] Jakob S., Gotterbarm G., Roth F.X., Effect of Rovabio $^{\mathrm{TM}}$ Excel AP on nutrient digestibility and on performance of piglets, Joint Meeting of ADSA, ASAS and CSAS, Quebec City, Canada, July 20-25, 2002.

[16] Kennelly J.J., Aherne F.X., Lewis A.J., The effects of levels of isolation, or varietal differences in high fibre hull fraction of low glucosinolate rapeseed meals on rat or pig performance, Can. J. Anim. Sci. 58 (1978) 743-752.

[17] King R.H., Lupin seed meal (Lupinus albus cv. Hamburg) as a source of protein for growing pigs, Anim. Feed Sci. Technol. 6 (1981) 285-296.

[18] Kluge H., Hirche F., Eder K., Concentrations of NSP and oligosaccharides in lupine species L. angustifolius, L. luteus and L. albus. 7. Tagung Schweine- und Gefluegelernaehrung, Lutherstadt Wittenberg, 2002, pp. 145-147.

[19] Kracht W., Nürnberg K., Schumann W., Fütterung von Rapsverarbeitungsprodukten und Rapssaat an Mastschweine und Broiler. Fat Science and Techology, Sonderausgabe 2 (1993) 562-567.

[20] Meier C., Hagemann L., Gelbe Süsslupine als eine Eiweisskomponente in der Schweinezucht oekologisch produzierender Betriebe, 108. VDLUFA-Kongress Trier, VDLUFA, Darmstadt Germany, 1996, pp. 215-218.

[21] National research council: Nutrient requirements of swine, Tenth revised edition, 1998.

[22] Nürnberg K., Kracht W., Nürnberg G., Effect of feeding rapeseed oilmeal on carcass and fat quality of pigs, Züchtungskunde 66 (1994) 230-241.

[23] Pearson G., Carr J.R., Lupin-seed meal (Lupinus angustifolius cv. Uniwhite) as a protein supplement to barley based diets for growing pigs, Anim. Feed Sci. Technol. 1 (1976) 631642.
[24] Quemener R., Improvements in the high pressure liquid chromatographic determination of amino sugars and $\alpha$-galactosides in faba bean, lupine and pea, J. Agric. Food Chem. 36 (1988) 754-759.

[25] Rademacher M., Sauer W.C., Jansman A.J.M., Standardisierte ileale Verdaulichkeit von Aminosäuren für Schweine, Edition, Degussa-Hüls AG, Frankfurt/M., 1999.

[26] Rodehutscord M., Abel H.J., Friedt W., Wenk C., Flachowsky G., Ahlgrimm H.-J., Johnke B., Kühl R., Breves G., Consequences of the ban of by-products from terrestrial animals in livestock feeding in Germany and the European Union: Alternatives, nutrient and energy cycles, plant production, and economic aspects, Arch. Anim. Nutr. 56 (2002) 67-91.

[27] Roth-Maier D.A., Kirchgessner M., Nährstoffzusammensetzung und Futterwert verschiedener weißer und gelber Lupinen (Lupinus albus L. und Lupinus luteus L.) für Schwein und Geflügel, Agribiol. Res. 46 (1993) 218-228.

[28] Roth-Maier D.A., Kirchgessner M., Feeding of white and yellow lupins (Lupinus albus L. and Lupinus luteus L.) in combination with enzyme supplements to piglets, Agribiol. Res. 47 (1994) 312-317.

[29] Roth-Maier D.A., Paulicks B.R., Blue and yellow lupin seed (L. angustifolius and L. luteus) in the feeding of Pigs, 10th Int. Lupin Conference, Wild and Cultivated Lupins from the Tropics to the Poles, Laugarvatn, Iceland, 19-24 June, 2002.

[30] Rundgren M., Low-Glucosinolate Rapeseed Products for Pigs - A Review, Anim. Feed Sci. Technol. 9 (1983) 239-262.

[31] Schöne F., Fütterungsempfehlungen für Raps und Rapsprodukte, Lohmann Inf. 3 (1995) 11-14.

[32] Stoll P., Rapeseed by-products for fattening pigs, Agrarforschung 3 (1996) 223-225.

[33] Taverner M.R., Sweet lupin seed meal as a protein source for growing pigs, Anim. Prod. 20 (1975) 413-419.

[34] Tei A., Wink M., Isolation and identification of quinolizidine alkaloids in lupins by GLCMS, in: Santen E. van, Wink M., Weissmann S., Roemer P. (Eds.), Lupin, an ancient crop for the new millenium, Proc. 9th Int. Lupin Conference, Klink-Müritz, Germany, 20-24 June, 1999, pp. 273-277.

[35] Wetscherek W., Lettner F., Huber H., Rapeseed oilmeal and field beans - protein sources for fattening pigs, Der Förderungsdienst 38 (1990) 97-101.

[36] Wetscherek W., Zollitsch W., Lettner F., Rapeseed oilmeal in supplementary feed for pig fattening with maize cob silage, Bodenkultur 43 (1992) 363-370. 